\title{
Teacher as an anonymous moral agent of universal good: discussion on the role of teacher in the short story 'The Morning Clouds' by Yasunari Kawabata
}

\author{
Mahesh Hapugoda* \\ Department of Languages, Faculty of Social Sciences \& Languages, Sabaragamuwa University of Sri Lanka, Belihuloya, Sri Lanka.
}

\begin{abstract}
This paper investigates the philosophical applicability of the Kantian notion of teacher to interpret the short story, The Morning Clouds by Yasunari Kawabata. Though the role of teacher has broadly been discussed in various pedagogical contexts, in a postmodern time like today the teacher's role as a moral guide is often discouraged and his/her intervention is reduced to a facilitator, while his/her existence is often believed to be duplicated by a computer. However, the teacher is still treated as an entity of reference and role model, because $\mathrm{s} /$ he is believed to be capable of transmitting the message of 'universal good' and implanting moral values in students; the future of any society. A moral agent as 'a rational and free being who is capable of acting with reference to right and wrong' is perceived through the social role of a teacher who guides students to a final moral destination. Such action must be based on a 'priori', a Kantian social essential created in the human mind for universal good, as an act of faith for the preservation of ultimate human values. Teacher as a personal identity may be of little importance as far as a 'priori' functions as a signifier in students' minds, but the teacher's obligation to the moral entity and exemplification seems the most important aspect since students, especially when they grow into adulthood, take $\mathrm{him} /$ herself as a role model. Therefore, as a teacher, one should place him/herself beyond personal interests because of the unconditional and universal responsibility towards 'the other' (his/her pupils). In this respect, this paper examines how the teacher in the short story, The Morning Clouds, sets a unique example as to how a teacher should act before students as an idealised moral guide, and attempts to justify the legitimacy of teacher as a universal moral guide who could design the destiny of future generation.
\end{abstract}

Keywords: Teacher as a moral agent, education, Kawabata, Zizek, Immanuel Kant.

\section{INTRODUCTION}

The crisis of modern education, higher education to be more precise, is getting more and more complex every day. Under the present techno-capitalists economic model, the role of education has been subjected to serious changes in adapting to undeniable demands of the system (Bauman, 2012; Oxenham, 2013; Newman \& Couturier, 2004; Mandel, 1971). At least in the last few decades where "irresistible and irreversible globalisation" (Hardt \& Negri, 2000) has emerged as a new global order, there has always been an inconsistency between the fast evolving requirements of the new capitalist economic structure and the older form of knowledge building process, its applicability, legitimacy and emancipatory potential. Until today, to a far greater extent, modern education is left clueless before the common grievance as to how someone with modern knowledge orientation can 'survive' in the present postmodern consumerist world. However, exploring on the new forms of structural changes in the wider socio-economical outfit, Bauman (2012) notices that education is subject to deinstitutionalising pressure and the teaching departments have lost their autonomy to determine what to teach since the teacher-student relationship has been reduced to that of a supplier-client. Similarly, in relation to American higher education, Newman \& Couturier (2004) feared that the changes proposed to higher education would possibly generate "new and unexamined structure that undercut higher education's traditional purposes". They further examined the fact that no institute has set out a clear statement about what the student is expected to learn in terms of knowledge (Newman \& Couturier, 2004). Given the instantaneous and drastic changes in the consumerist capitalist market, it is obvious that no syllabus with modern educational objectives can ever design a fixed set of learning outcomes to match with the so called skills and competencies that are supposed to be passed on to students. 
In a somewhat traditional sense, the contemporary liberal education, despite its inherent bourgeois limitations, aims to inculcate in students broader values of human existence, meanings of life and world, human virtues and absolute truths by going beyond vocational functionalities. Therefore, modern education has a strong ontological and epistemological background to its teachings. Under liquid modernity, with the collapse of metanarratives and the growing incredulity towards rational discourse of the previous era, individuals are expected to indulge in a new form of freedom where 'survival competencies' (Oxenham, 2013) are mostly highlighted in their higher education. Oxenham (2013) observes that,

"liquid education dismantles previous higher learning, that it pursues temporary, tentative and unarranged bits of knowledge and that it focuses on helpful competencies".

He claims that talking about modern education in a 'post-historical reality' is a paradoxical mismatch of the era. Oxenham (2013) states;

"Education in liquid modernity wastes no time in generating grand cultures that have no place in its ontological outlook. Culture has been liquefied, and in its place, performativity, the generation of profitable skills and the mechanization of knowledge are becoming the new legitmation of education".

All these observations prove what Mandel (1971) prophetically said nearly four decades back;

“... under late capitalism, the role of higher education is redefined, being no longer produce "educated" men with judgment and propertyan ideal which corresponded to the needs of freely competitive capitalism - but to produce intellectually skilled wage-earners for the production and circulation of commodities".

In this context, when the integrity of knowledge of the previous era is perceived to be illegitimate and inapplicable in terms of day-to-day survival, the person who carries such world view is also viewed as 'outmoded'. Since the role of teacher as a 'change agent and role model' (UNESCO, 1998; Barth, 2001; Chen, 2005; Badley, 2006; Lattimer, 2012) has become indefinable in the present technocratic world for both the educators and learners, the identity of a teacher seems to undergo a serious testing phase in determining the true existence in this postmodern society. UNESCO, in their World Education Report issued in 1998, stresses that,

"The importance of the role of the teacher as an agent of change, promoting understanding and tolerance, has never been more obvious than today. It is likely to become even more critical in the twenty-first century".

Yet, when role models are digitally 'made' across a wide spectrum of popular media today, it is doubtful that students may follow the teacher as a role model at any stage of their lives. On the other hand, when the teacher is expected only to deliver a prescribed set of 'information' to their students and not to become a role model, the teachers in the present world easily escape into their own egocentric goals forgetting the universal duty to mankind. In this sense, it is often with teachers' blessing that the role of teacher has been subject either to be redefined to fit into the postmodern 'student-centered' classroom or narrowed down to the needs of utilitarian vocationalism today. In this context, the effort of this paper may seem old fashioned as it attempts to resurrect the notion that the teacher can still inspire students only if $\mathrm{s} /$ he chooses the right role at the right time, and only if $s /$ he is patient enough to inculcate values in students when they are tranquil enough to look into themselves. To explore the above idea, this paper travels through three main ideological terrains; Kant's philosophical approach to education, Zizek's idea of anonymity and the teacherstudent relationship between Miss Kikui and Miyako-san in Yasunari Kawabata's short story The Morning Clouds. Though the teacher's role in shaping student's moral life has been the subject of much literature, the notion of 'silence' and 'anonymity' as a powerful agent of carrying conviction is best portrayed in The Morning Clouds by Yasunari Kawabata.

The manner in which the relationship between Miss Kikui and Miyako-san grows until Miyako-san becomes conscious about her own launching into adulthood, evidences how the Kantian notion of education fits into the essential moral integrity that teacher should maintain towards his or her students. Therefore, Miss Kikui's role of teacher as a change agent derives from what Kant believes, "One generation educates the next" (Kant, 1900). In a Kantian world, teacher and his education were the paramount elements in transforming a child to befit to live in an age of discipline, culture, civilisation and morality. However, a teacher who represents the values of one generation was treated with reverence until knowledge became a commodity that could be exteriorised from the knower and made available through a machine for others to be retrieved and purchased. 
"The relationships of the suppliers and users of knowledge to the knowledge they supply and use is now tending, and will increasingly tend, to assume the form already taken by the relationship of commodity producers and consumers to the commodities they produce and consume. Knowledge is and will be produced in order to be sold" (Lyotard, 1984).

In a post-Lyotardian world, the teacher is no longer supposed to transmit any strong judgment about truth, universality or objective certainty to the students. Since knowledge has been divorced from truth (and radical change) in the latter part of the previous century, the postmodern world today does not expect him/her to share experience inseparably combined with wisdom. Since higher education is fast becoming a lucrative business where everything is determined by its 'use-value', the teacher is mostly asked to produce 'factual knowledge' devoid of its emancipatory impulse. Unarguably, under the new technocratic context, the teacher cannot be considered the sole source of disseminating knowledge. In addition to the truth that, starting from the Industrial Revolution and with the printing of the Bible, the hegemonic authority over knowledge and interpretation were historically challenged from the day that humanity invented a machine to store data, 'knowledge' could be retrieved, disengaged from its time and space. From this moment, there is no bearer or an agent who carries knowledge to another or in other words, the agent who operates in the open space between 'knowledge' and the person who 'needs to know' (or learner) gradually disappeared. Therefore, the Foucauldian paradigm of power and knowledge has now faced a significant structural crisis.

As Lyotard (1984) observed,

"...the miniaturisation and commercialisation of machines is already changing the way in which learning is acquired, classified, made available and exploited".

According to him, knowledge will survive, only if

"...it can be translated into quantities of information. We can predict that anything in the constituted body of knowledge that is not translatable into computer language will be abandoned. We may thus expect a thorough exteriorization of knowledge with respect to the "knower", at whatever process he or she may occupy in the knowledge process" (Lyotard, 1984).

He further observers that,

"Knowledge ceases to be an end in itself, as it challenges the old principle that the acquisition of knowledge is indissociable from the training of minds or even of individuals" (Lyotard, 1984).

The knower will be transformed to a new phenomenon of producer of knowledge, while the learner will be identified as the user. The old social bondage between knower and the learner will be reformulated as to who has the access to information these machines have in storage. If education existed for the need of social mediation between 'self' and 'other', under the new condition of 'self' and 'machine', its function has now encountered a legitimate crisis. At the same time, in the completely personalised digital space where 'the user' is often encouraged to choose anything without any moral guidance, the role of education as a moral guide has technically become defunct.

The teacher's role as a cultural agent who inculcates values in students is mostly forgotten in the face of the postmodern metamorphosis of teacher into a technical facilitator or a mediator with minimal ideological interference to students' moral and cultural life. Undoubtedly, there are exceptions to this fast evolving global scenario especially in the Asian contexts, where the teacher is still treated with reverence or as a role model though in a declining trend. One must keep in mind that the conventional reverence and blind faith too can distance critical thinking and analytical potential from students. However, under this atmosphere, the role of the teacher and his identity are viewed with a complex cultural attitude, where there is an obvious blend of conventionality and modernity. There are also complaints from teachers in both higher educational institutes and schools about students' indifference towards moral values in life, where they do not actually listen to what teachers envisage about their behavior. From a wider angle, social obligations in a higher moral life and achieving universal goals are fast fading away from the life world. As a result, setting a role model has also become a difficult task to be executed, since the wider picture is dangerously changing. Many university teachers are presently uncertain of engaging in 'philosophical inquiry' and are skeptical about serious academic dialogues. Universities do no longer stick to their modernist bourgeois plan to produce "the brightest sons to administer the nation" (Mandel, 1971) with higher ethical goals. In the present service economy, employers only seek efficiency and productivity in their employees and no longer worry about their moral character. Even academic disciplines are altered according to the needs of the changing job market, for example, teaching literature is mostly reduced to a tool of acquiring language proficiency. So, the socities ended up in a dismal time, where the teacher has not fully realised his/her unconditional responsibility towards 'the Other' since, 
"...the intellectuals are condemned to the choice of integrating themselves into the existing irrational and inhuman social order-disorder it might better be called!" (Mandel, 1971).

Despite the fact that the teacher can often be challenged on the ground of being too unreal and utopian, as far as his exemplariness in the act of building a better world is concerned, it does not de-legitimise the Levinisian stance "the great separation between the way the world functions concretely and the ideal of saintliness of which I am speaking" (Wright et al., 2001).

In a way, it is contestable that Kawabata's (1993) short story The Morning Clouds illustrates a traditional role of a teacher in the Japanese culture. However, in the scope of this discussion, the author does not intend to suggest that one must 'return to' some ancient form of social system for better examples. This paper simply investigates the interpretative potential of the nature of the relationship depicted in the short story in relation to its emancipation impulse. Even in its modern sense, unarguably, the teacher needs to develop skills in students, give them necessary knowledge and teach them what is immediately useful for their future. Therefore, a degree of classroom teaching and reinforcement of evaluation by the teacher are required. However, both inside and outside the classroom, the teacher must inspire self introspection in students and implant desire to embrace life positively. More than perhaps his/her engagement in the art of disseminating and transacting the contents to students which is the primary professional duty even under a modern context, the teacher has a universal responsibility to enlighten students about the nature of the world and duty to others, as well as how to improve existing primordial human nature to reach a universal destiny. Such an act would, in the long run, help this chaotic world to become a symbolic entity through collective human actions. The education that is exemplified even through the smallest actions today may ultimately create a better symbolic order tomorrow. Benefits of such action towards higher humanity may encompass all aspects of human life, from most worried 'life skill competencies' to mega political transformations.

It is notable that the impossibility to witness immediate results should not lead to a discouragement whatsoever. The teacher's organic ${ }^{1}$ involvement in such actions will inspire students to follow him/her as a model for which his/her symbolic role is an important determinant. In illustrating this 'organic involvement' in the sphere of human choice and setting a life example for the student to follow towards a universal finality, the teacher, Miss Kikui in The Morning Clouds can be ascertained as a sublime individual example. Her role as a 'conscious' non-communicator can be recognised as that of a cosmopolitan spirit which is 'unconsciously' engaged in the Kantian educational concepts.

"...duties to themselves and duties to others' and, therefore, 'bears within him/her (author's emphasis) a certain dignity that makes him/her more noble than all other forms of life" (Kant, 1963).

Her choice of 'silent communication' (or noncommunication) with Miyako-san, her student, brought self introspection and realisation for Miyako through which she finally attained insight about life leading to eventual maturity. The only 'teaching' that occurred between these two was that one allowed the other to pass the most difficult 'emotional phase' to reach the pacified 'rational phase' of existence without exploiting the vulnerability of emotions for selfish goals. In bringing a human subject to a better future level, Miss Kikui's role as a teacher is treated in this paper as a Kantian pedagogical example of potential universal application.

\section{Objectives}

The following are the objectives of this paper:

a. To interpret the teacher-student relationship in The Morning Clouds in the light of Kantian education philosophy and to conceptualise how higher values can be inculcated in students even in a non-dialogical vacuum. The paper identifies that a true relationship is something that is effortlessly understood with maturity (with time). Metaphorically speaking, when the teacher becomes a 'mirror' through which the students see their own reflections, the discussion of this paper then focuses on how the role of teacher can be reinterpreted to 'legitimise' his existence in the present post modern world.

b. To see how Kantian educational values can be appropriated in relation to the symbolic existence of Miss Kikui to re-invent the teacher, while suggesting to the postmodern civilisation to revisit the moraleducational philosophy of Emmanuel Kant for reintroducing higher moral values of the enlightened modern project to the present post-ideological world.

c. To re-investigate the nihilistic postmodern discouragement that the teacher should only 'facilitate' the learner in the classroom without a serious ideological involvement or motivation in determining the moral and cultural life-world of students. 


\section{METHODOLOGY}

This paper is basically structured as a literary analysis. The content of the short story is reviewed in the light of Kantian educational theories and motives, while contextualising the legitimacy of the teacher in a postmodern world. While reviewing the existing literature on the changing role of teacher from modern to postmodern education, the paper investigates the possibility of giving a different interpretation to the development of the student-teacher relationship in the short story. Comparative and analytical methods are used to articulate modern theoretical and ideological developments to comprehend the role of teacher found in the character of Miss Kikui in the short story. In addition, modern developments in educational theory, semiotic analysis and Zizek studies will also be used to understand the characters Miss Kikui and Miyako-san and their inter-personal relationship in the classroom as well as outside.

\section{DISCUSSION}

It may seem strange or outdated or even old-fashioned to invite a young reader who carries a smart phone wherever $\mathrm{s} / \mathrm{he}$ goes to return to a much discussed dialogue on the role of teacher in the global context today. Further, it will equally be a tasteless affair for such reader to revisit a philosophical dialogue of morality in relation to a nineteenth century philosophical discourse of analysing a literary text; one which is written in an Asian context. Yet, on considering how fast the governing hegemonic principles of the modern world are collapsing and man's unpreparedness for the approaching catastrophe of humanity, one is compelled to seriously re-think of the values that man has chosen to live with during the last two centuries. At the same time, the certainties of social sciences which guaranteed a utopian human finitude have disappeared from the social milieu and the 'truths' they brought forward to humanity bear no validity today. The entire academic discourse is overshadowed by a greater skepticism which further risking those who believe in universal and absolute values. Mega socio-political projects such as Liberal Capitalism and Socialism were based on utopian ideological impulses of a better future world. The academics and contemporary intellectuals who fell into either one of those camps subsequently attempted to breathe the emancipatory ideological wind and passed on that brand new vision across the globe through their student population who then carried on that legacy. For the latter segment, academics in humanities were the most highlighting set of people who translated the 'message' to everyday human life. As Wallerstein (2004) observes,
"The three principle disciplines that were created to deal with the modern world - economics, political science and sociology - all opted to be nomothetic, by which they meant replicating to the extent possible the methods and epistemological worldview of Newtonian mechanics".

As pointed out above, when the individuals in the present context are more concerned with survival than meaning in life-world, moral judgments that result from greater ethical-ideological background are not considered important in higher education. In this skeptical anarchism, the existence of true teacher appears to be more and more needed to determine the fate of the next generation. In a classroom one should not forget, even in this techno-postmodern world, that the teacher's integrity in ethical values is often observed by students. They evaluate the character of their teacher on the trustworthiness of the authentic interconnectivity between what they teach and the genuineness of their practices (the students may openly not say so, but they will internalise the 'contradiction' and subsequently lose faith in such integrity itself). The teacher as a moral educator has to be materialised, then, through exemplarily enhancing students' thinking to the next higher level of moral reasoning, although the Kantian motto that 'the classroom education is fundamentally and inevitably moral in nature' has been forgotten in both secondary and tertiary education. In this context, the genuine example that is set by Miss Kikui in the prolonged 'relationship' with Miyako-san exemplifies a teacher's committed making of a role model to transmit psycho-sexual lessons through moral reasoning in an event when a student is metamorphosing into adulthood. Rather than just pedagogically describing to students what is correct, she sets an example through her life in the fairly short term of service in the provincial Japanese school. Her personal identity seems not very important as she is initially introduced to us as 'that person' (Kawabata, 1993) which is defined in this paper as an 'anonymity' (not simply as the 'namelessness' but 'more- than- name'). Yet, as a formative task of education, her act as a representative of moral values directs at fostering the personal identity of students whose moral and pedagogical integrity will guide the society for a better destination tomorrow. She was not carried away by immature emotions and desires but became "...obedient to the dictate of reason..." (Kant, 1963). And, on the account of moral autonomy of the enlightened man, Miss Kikui plays the noble role of a moral agent of universal good.

Rather than giving subject-related information for educational purpose and developing necessary competencies for survival, as said above, little is supposed to be taught in the classroom with regard to life, its 
meaning, symbolic achievements and even on how to relate to the social other. From religion to postmodern television, broader spectrum of social institutes have taken up the role of guide for life today and the teacher may not be the only one who holds the sole authority to shape students' moral universe. Since the teacher him/herself has been a subject of the survival game in the modern market commodification process, where millions of commercial signs have infiltrated into the domain of cultural life, we have subsequently lost the guide him/herself, and are confronted with a serious socio-cultural problem as to how students should be taught on the ground of higher morality. In contrast to the image of a teacher as someone who has conquered the subject matter and who views teaching primarily as a task of transmitting knowledge to students, the concept of 'master of thinking' implies someone who knows how to think and is committed to the activity of intellectual commitment of his/her own self. This means that the teacher as 'master of thought' also should go beyond the textbook itself, since it embodies a posture of 'organic-ness' in relation to his/her own practical involvement in what s/he knows: both before the text and before others. Hence, what is arguable is, in a pedagogical context, the teacher is not someone who merely transfers knowledge and information to students but is a living example of a role model and, by being a role model, s/he carries the message of universal good.

In a world where truth has no real meaning, scholarliness and knowledge building process are part of the entre simulacrum. Many university teachers, for example, do research mainly to score for their next promotion without any authentic desire to invent something new, or to reinterpret existing affairs and change things. It is in this context that the role of teacher is considered to be very significant for his/her commitment for duty is universal and unconditional. The Kantian assumption that "man has strong inclination to freedom" (Kant, 1963) should be actualised through the dictate of reason; education is an imperative vehicle for humankind to develop its own self and to humanise its animalistic drives. Education will bring him/her a perfection that $\mathrm{s} / \mathrm{he}$ has never experienced before. According to Kant (1963), "A human being can become human only through education. He is nothing but what education makes him of". A man should obtain a universal knowledge that involves acquaintance with and reflections on the entire species and this idea travels beyond the scholarly knowledge of knowing the world.

\section{Who is a Teacher? Defining Kantian Teacher}

The general definition of teacher is a difficult and broader one. Teacher can be the one who appears before the classroom or a person whom you suddenly meet in the street for a few minutes, yet the teacher analysed in the context of this paper is a person who guides someone to a certain moral end upon which the character's behavior is determined. This notion at present has broadened its scope to accommodate a machine in place of a person such as a computer which assists to disseminate information and this is commonly misunderstood as knowledge. Machine, as an effective and efficient device of transmitting knowledge across the boundaries of the Nation State, man seem to play the role of a teacher, thereby legitimating a common definition of a teacher as someone who imparts knowledge. Since the teacher is a window through which many young learners see their future, the teacher functions as a role model too in the wider social atmosphere, rather than just communicating information or knowledge to students. Even 'the knowledge' that is supposed to be transmitted has undergone significant changes. Moral education especially is no longer considered to be an essential component in the postmodern teacher-student pedagogical relationship. On the other hand, the decline of the discipline of Humanities has terribly affected the theoretical discussion on the role of the teacher and the legitimation of his existence. The Kantian teacher needs to understand the condition that a man is not to be viewed as a means but as an end in itself. Hence, mankind has a greater obligation to fulfill while s/he is alive. S/he has to work on the idea of duty to love other fellow men (and women) in order to place humanity in a higher position.

In the present, where all values and ideals tend to collapse before profit motives of the global capital, education is also caught in the whirlwind of primary survival. The contemporary era that we live in today is a time when the role of teacher is skeptically understood and many teachers deviate from universal goals towards egoistic purposes. There are a lot of doubts as to whether $\mathrm{s} / \mathrm{he}$ is capable of changing students to a higher moral level. From Lyotard onwards there are also doubts as to whether such change is really necessary in this postmodern context where, more than morality, money is viewed as the utmost value in the life world. But it is exactly in this degradation that morality plays a significant role. Everything is estimated on its financial value and human choices are made depending on whether your daily acts can be swiftly converted to money. In the present day Sri Lanka, for example, the teacher's role is quickly metamorphosing from someone who transmits universal values to students, to a businessman who can profitably market education for personal survival. The teacher today does not even know whether they are engaged in an immoral act itself when they choose to sell, because the Master-Signifier (S1) (Figure 1) that determines good and bad has sadly and dangerously disappeared from the life world. Therefore, there is no cognitive map to guide individuals of the present day society towards any 
universal good. In short, we all are lost without proper direction and struggle for some meaningless survival.

It is important for any society to maintain a set of values and code of ethics which would function as a common agreement for a majority of its members to accept and share. According to Zizek (2007),

"we signal our acceptance to what others accept with Master-Signifier which serves as the rallying point for all the others".

It constitutes a trans-subjective structure which predetermines the subject's place. Therefore, the word 'teacher' posits a very 'objective' frame of reference which allows for my 'subjective' identification (Zizek, 2007).

$\underset{\rightarrow}{\operatorname{Master~Signifier}(\mathrm{SI})}$

What is good/bad? an illegal migrant who emerges from the sea, a threat to capitalism in which people blindly opt for commercial benefits without seriously considering the adversities, etc. In this interpretive milieu of various meanings, it is the shark that constructs and re-organises the society in its image. The shark reminds us of the conditions of capitalist society that we have otherwise forgotten in our daily thinking. We would not have thought of these ideological situations if not for the monstrous presence of the shark that threatened our immediate existence.

The Master- Signifier is a 'signifier without signified' and forms a stable symbolic order. These are signifiers that subject and most deeply identify with and play a significant role in the way someone gives meaning to the word. According to Lacanian interpretation, a MasterSignifier is empty because the referent or the concept

Figure 1: Master Signifier

A master-signifier constitutes the kernel of the object's identity which is designed by the same signifier. This is a fundamental operation of self-referentiality, where the meaning has to be derived through the difference between elements (the signifier itself as pure differencethe difference between the tuition teacher and the teacher in a very difficult school environment with poor facilities and low salaries). On other occasions, meaning is ascribed through some pre-existing signification, where things referred to as an empty signifier is retroactively seen as what is being referred to in comparison. In this case, someone's attempt to design a meaning to a commercialised education context where teaching is done in exchange for money by saying, "I became a tuition teacher because the school education is hopeless and there is no job satisfaction" would be a pedagogical example for this misinterpretation. Similarly, in some other context, the excuses that certain politicians make in justifying their crossovers due to pure personal reasons in the recent history will be political examples. All this is possible or justifiable on personal grounds because there is no singular governing body or authority to regulate our behavior. Hence, there is nothing that individuals can represent except their own micro desires. To explain this further we can go to the figure of shark in the movie Jaws (1975) by Spielberg. The shark is a representative of many things such as the forces of nature fighting back humans who exploit the environment, the eruption of sexuality as the natural big-Other who restricts our enjoyment, a threat from the neglected Third World to America as signified by any Master-Signifier will always be something impossible for a subject to fully comprehend. It is an ideal where the signifier carries no signified of its own and stands in for the fullness of the meaning of the symbolic system itself. Since it does not demand a marker of difference so that we can continue to hold it out there as something to strive for what is not achieved, it is a perfect ideal which is not part of the chain of signifiers that determine the meaning of a particular signifier. A Master-Signifier stands independent of other meanings that function in opposition to each other and, therefore, does not depend on the binary oppositional function of $\mathrm{S}$ and non-S $(\mathrm{S}=\mathrm{S})$. The teacher who is portrayed in the short story The Morning Clouds stands for an independent existence since it does not require to posit against its opposite to discover its meaning. For example, Miss Kikui's existence as a teacher does not depend on her predecessor; the literature teacher who thought that he did not belong to this rural school (though he was of some character to impress his students, he is completely unproductive as far as the junior classroom context is concerned). She becomes unique by her own deeds and never comments over what the previous teacher was doing, which was nothing but a purely narcissistic selfindulgence. Her uniqueness is therefore, self-referential and can only be judged through a universal agreement of values about unconditional devotion to professionalism. Her being in the profession and duty to others are hence governed by values which make herself sublime not only in the mind of Miyako, but also even in those who read the story. 
The Master-Signifier is a primary way of conceptualising the symbolic order that organises a society. Every culture has a particular way of doing things and one can explain it to a certain extent. Afterwards an arbitrary point comes beyond which no explanation is possible. In this short story, Kawabata carefully depicts the operation of the Master-Signifier in the Japanese tradition, where teacher is considered as an object of reverence. In the Morning Clouds he linguistically constructs the mega societal element of 'this is how we do things' or, in other words, the way things have been organised and the way the relationships are structured through some historically evolved value system. Obviously, though this paper tries to rationalise the relationship between Miss Kikui and Miyako, the structural function of a particular Master-Signifier is actually beyond the coordinates of logic; the bedrock of symbolic order itself. However, from the beginning till the end, it is the intervention of the Master-Signifier in this story that mysteriously brings about a meaningful order to the 'confused relationship' between Miss Kikui and Miyako. In addition, in relation to education, there is yet another conceptual aspect that we can always borrow from Kantian philosophy.

As a true son of the Enlightenment, about a century ago Immanuel Kant's (1724-1804) contribution to modern philosophy in particular, and to Western civilisation in general had been remarkable. A significant amount of his conceptualisation aimed at formulating a code of ethics for future humanity, when he combined reason with man's strong inclination to freedom. He observed that man must be "accustomed from an early age to accept the dictate of reason" (Kant, 1963). In this regard, Kant thoroughly believed in education as a means of transforming people to a more cultivated level. Kant's education focuses on enhancing the critical ability of man and then unveiling the truth; and, according to him, "a good education holds the great secret of the true perfection of human nature" (Kant, 1963). His way of education targets in producing an individual with a cosmopolitan spirit "with a commitment to all that is good in the world" (Kant, 1963) and the substance that is taught to students in today's classroom should not target simply to achieve the present level but a possible better future and an advanced level of human race "taking account of the idea of mankind and the universal destiny of man" (Kant, 1963). According to Kant (1963), good education can bring about a gradual improvement in the world and each successive generation can take an individual step towards the perfection of mankind. Therefore, Kant (1963) claims,

"...education is therefore the greatest and the most difficult problem with which man can be confronted, since insight depends on education and education in its turn depends on insight".

Kantian education assigns following tasks for teachers;
a. Disciplined thinking
b. Creation of a cultivated outlook
c. Enhancement of civilisation
d. Imparting moral rectitude

During his days, Kant was happy about the first three steps in practice in the Western educational context, but was skeptical about the way in which morality was conceived and imparted to society. He observed that "we are living in an age of discipline, culture and civilization but an age of moral rectitude still lies in the distant future" (Kant, 1963). Understandably, the application of moral component would have been 'difficult' during his days. Yet, nearly hundred years later when the short story The Morning Clouds was written, Kawabata might consciously have kept the significance of the necessity of the Kantian moral universe in his mind in relation to the realities he came across in Japanese society. When we re-read the story in the present value-free context, a comprehensive re-articulation of Kantian moral education is required to fight the evil that overwhelmingly overshadows civilisation. For instance, we now live in a context where higher education institutes hire trainers to train academics, which even justifies bringing in the world's most condemned dictators, their life styles or speeches to enhance classroom motivation and improve 'soft skills'2 of students. This is a symptom of a society which has lost its "desire for a better way of being" (Levitas, 1990) and has lost trust in the idea of a "perfect, ordered and regimented world" (Stavrakakis, 2005). It is also a symptom of a disorientation of our life world, where societies are condemned and forced to accept the banal realities of the commoditised world. However, it is also equally important to keep in mind that the utopian meaning (like the concept of teacher that is advocated in this paper) "arises in periods of increased uncertainty, social instability and conflict, when the element of the political subverts the fantasmatic stability of our political reality" (Stavrakakis, 2005).

Kantian moralisation directs mainly at young learners whose moral character will determine the nature of future citizens of the world. Children should be educated to 'perform duties to themselves and to others' and their moralisation also means persons should develop attitudes to choose good purposes only and 'the good purposes are those which necessarily secure universal approval and may, at the same time, be the purposes for everyone' (Kant, 1963). In this regard, Miss Kikui never attempts to 
exploit Miyako who has developed a strong emotional attraction towards her new teacher on primary instincts. Despite the fact that Miyako is almost hypnotised by her teacher's growing beauty and is psychologically ready to receive Miss Kikui's romantic attraction, she never develops the relationship to disturb her growing awareness about a higher moral universe. In front of Miyako's countless letters exploring her emotions, she becomes silent which can be understood as a very important approach in teaching and counselling. In this case, silence is communication. Through silence, Miss Kikui shows her character and Miyako's immaturity and emotional sensitivity that has blinded her reason. Rather than spoiling the entire relationship to a level where words can irrecoverably damage the child's psychology, she turns towards serious and everlasting noncommunication (non-rational symbolic bedrock) which is stronger than millions of words, until her rational mind starts to bloom. Miss Kikui's 'love' reaches a universal moral level simply because she educates her students to go beyond the immediate material standards of the world that they live in. According to Kantian moral philosophy which states "human being bears within him a certain dignity that makes him nobler than all other forms of life" (Kant, 1963), this quality makes Miss Kikui a teacher with dignity even in a limited space. She acts as if she exactly knew the Kantian motto that "good education is capable of bringing about a gradual improvement in the world" (Kant,1963). Though not in exact terms, everyone has internalised the value of education and its potential to humanise man, and that 'internalised value' itself functions as agent or guide in making our choices towards future.

\section{Difference as self-referential}

Further, as explained earlier that a Master-Signifier functions as an ideal, there is no 'reference' possible to any existing meaning or concept that it represents. The concept of 'good' is defined not in relation to another component or opposition, but in relation to the object itself. In other words, the truth exists even in the absence of the false. Therefore, it does not require any comparative/contrastive element (the difference demarcated by the function of a binary opposition) in the opposite end to define its meaning.

The above theory is effectively applicable to the teacher who justifies the act of conducting private tuition (or any other act that halts proper teaching in school or university environment) simply because school education is hopeless and there is no job satisfaction. One can easily distinguish 'tuition masters' who are ready to sell 'teaching' or 'knowledge' to earn money without any moral of ethical upper ground. Yet, those who sell their intellectual capacities or abandon their social responsibility under the guise 'disappointment resulted from some structural collapse' are the real ideological culprits. Rather than those who openly 'misuse' the system for their own benefits, the latter are the ones who use an ideological cover to obscure their inner guilt. They are fully aware of the immoral nature of their survival act and what is meant by that act is that "they know what they do but they nevertheless do the same" (Zizek, 2002). Figure 2 can be altered as Figure 3.

When the teacher functions as a Master-Signifier it is always self-referential and never functions in relation to other signifiers such as 'private tuition teacher'(the one who teaches for financial benefits), 'lethargic teacher', 'teacher with family problems' or 'teacher who comes from far away'. The meaning is determined by the uniqueness of the meaning earned by the respective teacher in the ground. The meanings of the other signifiers are also designed by the weight of the meaning of the master signifier.

\section{Man and Choice}

It seems that man does not entertain an absolute freedom in what $\mathrm{s} /$ he wants. We are actually chosen by history to perform a certain historical duty in a historical time.

"There is nothing you can do about being chosen.

That's how it is. We go through life being chosen over and over again" (Kawabata, 1993).

The reason why Kawabata does not mention who actually chooses us in the above statement is because the choice is always of the call of history which determines

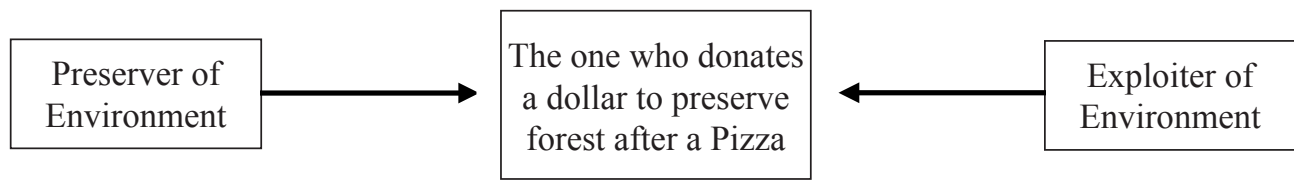

Figure 2: The true function of ideology is that the culprits hide behind the curtain of consumerism; they neither authentically participated in the act of truly preserving the environment nor they openly show that they exploit nature even at the moment of purchasing a Pizza. They falsely 'signal' that they care for nature while concealing their guilt through a compensating dollar. 


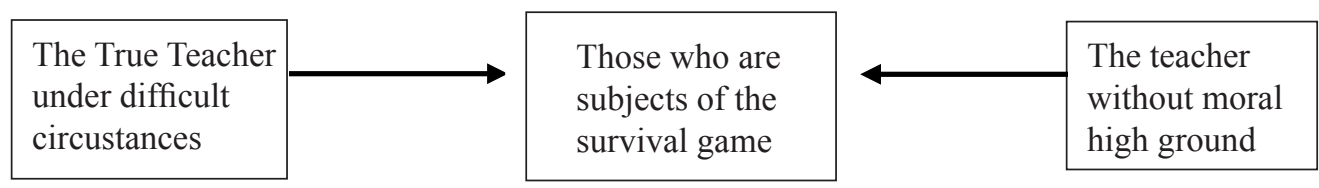

Figure 3: The ideological mystification and complexity created by the primary survivors who justify their immoral choices by wrongly pointing the finger at the system.

our fate. Therefore, once again the 'subject' in the short story remains anonymous. However, the role of teacher is also designed by certain historical needs in civilisation, but the teacher's duty to refine the unrefined (the animal unruliness in man) remains unchanged over time. The usual theorisation which implies that those who are trying to sell education are responsible for the degradation of the role of teacher in particular and education in general cannot be completely true, since man is capable of doing otherwise in his choices. From an existential point of view, we become what we are through our choices and our actions define us. Man is free to choose what one should be and enjoys full authority over one's own actions in transforming oneself infinitely. Man (includes woman) is responsible for his/her actions, is also responsible for everyone because when man chooses, it is a choice for all. $\mathrm{S} / \mathrm{he}$ is responsible for everyone because $\mathrm{s} / \mathrm{he}$ chooses for mankind. Man creates an image of what ought to be. Hence whoever who chooses puts a universal value to his/her act. This choice creates an image or a belief that all persons in this situation should act in this manner. As Sartre (1946) points out,

"I can always choose, but I must know that if I do not choose, that is still a choice. This, although it may appear merely formal, is of great importance as a limit to fantasy and caprice. For, when I confront a real situation-for example, that I am a sexual being, able to have relations with a being of the other sex and able to have children-I am obliged to choose my attitude to it, and in every respect I bear the responsibility of the choice which, in committing myself, also commits the whole of humanity".

It is correct that man's actions challenge the universal role model of the teacher in its appearance. This can illusionise the other aspect of the story i.e. there is an independent and unconditional existence for an individual to choose his/her own actions, thereby determining the possibility of preserving absolute universality of values. The signifier always appears against the background of its possible absence, which is materialised in the presence of its opposite. The ideal teacher has to be understood not against the 'sellers of education' (the tuition teacher or someone who makes profit out of education) but against the absence of a true teacher. Philosophically, it is very much similar to the way we understand the existence of the day. According to Zizek (2002),

"The human being posits the day as such, whereby the day is present as day- against a background which is not his concrete background of night but the possible absence of day whereinto night is located, and vice versa, of course".

The absence of teacher (the disappearance of a true teacher) is not a result or a condition created by a tuition teacher (a condition misleadingly understood against its absence) but an absolute absence of the subject itself. Similarly, there is a trend in the students to forget their teacher mostly after they accomplish their educational goals. Rather than blaming students, we the teachers, should reflect on the 'duty' entrusted on them. Whether we have been just the ordinary (easily forgetten by replacing with someone else) or above ordinary (where our role cannot be performed by another) is the question we should ask ourselves. When the values that the teacher has taught anonymously helps the student in his/ her life struggle, whether s/he openly admits that or not, the teacher becomes alive again, not only in his/her own life but in the lives of everyone else. Hence, the teacher does not depend on someone's acknowledgment of his/ her existence, but by one's existence itself and by the consciousness of his/her duty towards 'the other'. By being a teacher, one has chosen to be something more than him/herself.

\section{Inspiration}

Students that we are exposed to teach are at a transitional junction in their lives where they are still undecided on the future social role that they are supposed to shoulder. Sometimes, they come to higher education for a better job, or may be their parents insist them to be 'someone' in society. Not only must a teacher inspire a student for better education, but s/he must inspire him/her to embrace life. Students' fragility in subjective choices and emotional responses towards the immediate physical world must be addressed with great care and they should be handled with an insight to transport them beyond the borderline of the immediate primary demands of the material world. In this regard, Miss Kikui shows her pupil in a silent way the right direction of life. She inspires her to embrace life. If she 
tried to exploit her for primary sexual desires or if she tried to explain higher moral lessons to her, perhaps she would have conceived that life is a disappointment, embitterment or a departure. This short story is a fabulous example that illustrates how silence or non-communication can at times be an effective mode of 'communication', where not words but behavior itself decodes a message of universal good in the minds of young learners. Such a teacher through her identity can be a master of thought or create the trust in students that such teachers do still exist. In this regard, the physical presence of the teacher in the classroom is still justifiable, until at least a symbolic value system itself takes up that role.

The inspiration that she implants in her pupil helped her to orient towards an inner insight when she gradually grows old. As a good teacher, she has realised that there are certain things that cannot be taught and it is where non-communication comes into play. The short story remarkably portrays Miyako's growth into adulthood. The teacher has realised that Miyako's psychological struggle was originated by a touch of narcissism and she waited until Miyako preceives the truth about her own physical growth. When she becomes aware of the truth about life, her beloved teacher disappears from her town. She was there for her when she did not understand her but when she is old enough to understand her, she is not there. Therefore, Miyako could not give her a name (an identity through her material existence) but she leaves a symbolic universe (a nameless universe) before her as a mark of what Miyako should do for her own students in future. The constant reference to the clouds and the sky throughout the story especially in the beginning and at the end denotes that the teacher emerges from the infinite universe mysteriously as an 'angel' who inspires us to do 'good things' and guides us towards a right direction. In the same way, the recurring 'that person' in the story adds more to the mysteriousness or the anonymity of the de-personalisation of the material existence of a character. Though the distance and the non-responsiveness that Miss Kikui creates in the relationship can be defined as an escape from 'falling into' the traumatic Real, what matters here is that she did not follow her animalistic instincts of pleasure. However, the inspiration that Miss Kikui created in her pupil makes us remind of what Arendt (1998) once said about Heidegger,

"Thinking has come to life again; the cultural treasures of the past, believed to be dead, are being made to speak, in the course of which it turns out that they propose things altogether different from the familiar worn-out trivialities that they have been presumed to say. There exists a teacher; one can perhaps learn to think".
However, the inspiration to love the world, to embrace it and to make it better should be planted in the students' mind at a very early stage without exposing them to fundamental contradictions in existence. It is however true that a child has to undergo Oedipus castration at an early childhood, and the prohibition enforced by father's law makes him 'normal'. Though it is paradoxical to note that only 'prohibition' (a contradiction) can implant the desire in man to seek a love object in the wider society, what functions in the short story as a regulatory agent is the Master Signifier of a teacher (the culture). She carries within her character of absolute silence, the core values of the Japanese tradition which function as a universal mirror of or reflection for entire humanity. According to Zizek (2002),

"The external law regulates pleasures in order to deliver us from the superegotistical imposition of enjoyment which threatens to overflow our daily life".

Despite the above Freudian paradox between Oedipus castration and normalness, during the socialisation process a child should absorb the positive aspects in life in order to love the unknown future. In the short story, Miss Kikui is extremely careful not to engage in a romantic conversation with Miyako even though the space is created by her student. She instinctually seems to know that such engagement can destroy Miyako's future inspiration to embrace life. Rather, Miss Kikui observes a severe silence, giving the full space of the 'discursive play' (secret glances, anger, anxiety and writing letters, etc.) for Miyako’s young energy (perhaps unruliness), which according Kant (1963), is a "power in a way which would be harmful for themselves". However, once Miyako realised that the psychological dilemma is within her (not outside her), she beautifully overcomes her narcissism of self-love. All she wanted was time to grow and her teacher understood that. Just by not misusing the ideals of a child at a fragile time, Miss Kikui preserved Miyako's inner spirit to love the world.

\section{Anonymity}

A signifier can function in determining someone's value system and the way one responds to a particular social circumstance. The value remains in the individual's mind even in the absence of the teacher as a body. 'The Nameless-ness' or the 'de-personalisation' is a condition where a value system itself takes up the role of an individual even without his/her bodily absence. A soldier may follow his/her superior's orders simply because of his/ her immediate responsibility to his/her profession or it may be as a result of his/her obedience. We have also 
seen occasions where some soldiers, once detached from the command of the immediate officers for a long time due to combat situations (may be left in the jungle or deserts for months and years), they still subconsciously direct themselves towards the previously determined destinations. The guide is not bodily present in this case though positioned at a distance. Sometimes, without any previously determined conceptual framework and destination, individuals seek 'justice', 'righteousness', 'good', or 'freedom' through some institutional drives without any immediate or distant guidance. The theoretical use of the term anonymity signifies the latter situation. During the days of the 'Facebook Revolution' in Egypt, Zizek (2013) noted that these youths in the main streets and the Tahrir Square gathered just because "justice functioned as a mysterious universal agent" mysteriousness that is referred by Zizek is the possibility of the function of universal values in determining the direction of a political course.

The Morning Clouds begins with a clear anonymity of 'that person' who is literarily placed between classroom and sky; an arena of worldly reality and heavenliness.

"When that person was coming along the corridor that first day towards our classroom, she paused at the turning and look through the old window there at the sky. At the fringes of the clouds, there still lingered faintly the roseate hues of morning" (Kawabata, 1993).

"That first day" can refer to any first day in life, which is full of constant repetitions of things. The teacher paused at the 'turn' is symbolical as her arrival demarcates a clear turning point in Miyako-san who from then on wondered why "that person stopped there and looked up at the clouds" (Kawabata, 1993). The precise change that Miss Kikui brings into Miyako's life is the self-realisation about certain important things in life such as romance, maturity, adulthood, education and relationships. Though Miyako is inspired by her teacher's beauty which pierced her heart "like an arrow" (Kawabata, 1993), the self-realisation is implanted in her through a profound silence. Her beauty has evoked a new life in Miyako. The author describes how the young students were physically attracted to the beauty of the new teacher through the following words, “...the beauty of the dance flowed into our bodies, and our blood burned in us" (Kawabata,1993).

From then on, however much she tried, Miyako could not communicate her true feelings to Miss Kikui, and the only form of conveying her love for Kikui was through continuous letters which Miyako wrote, to which there was no answer in return whatsoever. One day, when Miss
Kikui touched Miyako's shoulder, Miyako felt she almost fainted. While still passing her remaining younger days, she is overwhelmed by her teacher's beauty and she wants to be acknowledged by her. Inspired, enslaved and perhaps defeated by her beauty, Miyako seemed ready to grow up now. And she wants to be as beautiful as Miss Kikui, which is the only 'competitive avenue' for Miyako to come out of her psychological entanglement. "While avidly stealing glances at that person, I was also looking at myself" (Kawabata, 1993). Miyako still struggles with her own reflections that she establishes within her through her teacher's beauty. This is the stage where a teacher is truly needed as a guide.

Fortunately, Miyako's classroom received a new teacher at the right time, leaving an obsessive predecessor behind. Unlike the previous teacher who eagerly indulged in his own words, Miss Kikui had very little to say to the other, yet had more to exemplify through her own being. Even the little she says has to be understood from within our own souls. For instance, during the day of the farewell, she did not have anything readymade to scribe in students' autographs. She only wrote, "I pray for your happiness" (Kawabata, 1993); a statement which seemed extraordinarily simple for the students who, in turn, inquired what is meant by happiness. She says, "please ask yourself that question" (Kawabata, 1993). Isn't it true that every individual has to define his/ her own happiness in life? In that sense, she has made a very sensible, individualistic and progressive remark for those who are about to bid farewell for their school life and enter adulthood. Though it is not predetermined, what comes to her mind in this occasion is spontaneous and, therefore, authentic. To be happy and trying to make others happy encompass entire life, and it requires lot of dedication and care. Hence, it is not easy to come by.

On the other hand, Miss Kikui, against the expectations of her students, behaves very happily during the farewell hours. She seems to know that these younger ones are about to embrace their future as adults. They will entertain full liberty as adults and the time has come for them to be productive citizens for the country. Their immature days are over and now it is the time to exercise their 'freewill' (Kant, 1900). A teacher can only be happy if he or she has taught the children how to "use their freedom right" (Kant, 1900). After few hours, when Miyako walks back from the ceremony, she finally realises that those were the best words for a farewell,

“" "I pray for your happiness". I muttered to myself. It seemed to me that these were the best words for a farewell, that one could not say anything else" (Kawabata, 1993). 
Again, all Miyako needed was time. The last stage of her struggle for recognition starts with the liberty she entertains after her college life.

"I was at liberty, now, to tell that person all that I had secretly felt for her these past three years" (Kawabata, 1993).

Though she left school, still she imaginarily lives there, and all the daily events in her life are planned according to the school calendar, where her social 'other' exists. She addresses her own ego which is still deprived of some 'true essence' (as a conscious subject) and seeks out her object-desire in herself. Hence, she does not need a reply, is not discouraged by no-answer, and all she communicates to Miss Kikui through those unacknowledged letters is a self-communication (kind of black-hole which absorbs everything and returns nothing). Finally, after so many failed postal endeavors, one of her letters was directly handed over to Miss Kikui by her cousin, and "she just silently accepted it" (Kawabata, 1993). As a true teacher, she tolerates, absorbs and concretely and safely keeps Miyako's secrets within her; she never reacts to those inclinations, neither does she reject Miyako-san in a hurtful manner which, in case of the latter, can eventually destroy her love for society. She never even revealed anything to Miyako's mother when they met in the bazaar, except a very obscure remark "Shall I say she is a very headstrong girl? That the teacher had a lot of trouble with her?" (Kawabata, 1993). After this ambiguity, then came the usual encouraging and protecting words of a true teacher; covering up everything like a friend she says, "No, not at all, When I was a school girl, I was simple and straightforward just like Miyako-san" (Kawabata, 1993).

However, Miyako's true realisation also takes place during this time, and this is uniquely illustrated by Yasunari Kawabata. It begins with the emptiness in the blank pages of her diary which she has stopped after writing the unacknowledged last letter.

"At the end of May, when I opened up my diary, I was surprised. From the day I stopped sending letters to that person, my diary was blank. My tears fell, drip-drop, into the blank pages. I stared at those tears of mine. I thought it would be good if they soaked through any number of pages. With those tears, I would cleanse the dirtiness of my life. "I am not jealous, I am not jealous", I told to myself. Although that person had given me nothing, surely, in truth, she had given me a great deal. Dedicating my schoolgirl days to that person, I had been reborn. That person is my honored teacher, whom I was not to approach.
Unless I became a more beautiful, better person, I could not receive that person's word" (Kawabata, 1993).

During Miyako's struggle to metamorphose from childhood to adulthood, from passionate emotions to spirituality, the silence is all that was observed by her teacher. Though it seems that the teacher has not given anything, the true reward that is bestowed to Miyako is the self-realisation itself, which cleanses her sins. It is only now that she can objectively look at her teacher. Miyako dedicates her perplexed schoolgirl days to Miss Kikui, paradoxically speaking, to whom it actually belongs. Her schoolgirl days are nothing but an unconscious, reflexive self-indulgence with her teacher at the other end. Now she can break the mirror and look at herself independently. Miyako realised the hard truth that without being more beautiful in her spiritual life, there is no way to overcome her 'otherness'. With a great honor to her teacher, she leaves her past life there and moves onto future. She is a woman now.

Throughout the short story, the emergence and the disappearance of the teacher are aesthetically portrayed alongside the beauty of nature. Nature is always glorious, beautiful and universal. Miss Kikui is often positioned with the immaculate beauty of nature. The story begins with clouds and concludes also with clouds, something that separates earth from heaven. She was chosen by an anonymous historical force to guide its younger generation towards some ultimate goodness, and we are chosen by the same universal force to be obedient to such commands. "There is nothing you can do about being chosen. We go through life being chosen over and over" (Kawabata, 1993). This choice is historically made to perform an 'act of duty' which operates as a Kantian priori that "necessitates the will independently of all antecedent desires and all the ends previously set" (Wood, 1999). On the other hand, man has to make difficult choices sometimes upon the universal call of justice and righteousness. It is because of one's philanthropic love and selflessness that one gets a noble position above all other beings. The description of, "it was as if a brilliant loveliness had suddenly come from a far distance to be at our side" (Kawabata, 1993) shows that this ultimate loveliness and beauty that the pupils experience is a spiritual enlightenment brought to them by a distanced agent. Only an enlightened individual can experience maturity and share that feeling with others. It is as if those clouds hanging in the distant sky carry the message of 'becoming' or metamorphosing into adulthood. As the story goes on,

"And then something inside myself opened its eyes. Was it what is called my womanhood? When 
I thought that I was becoming a young woman the same as that person, pleasure overflowed in me" (Kawabata, 1993).

Miyako's happiness in this particular moment is derived from her physical and emotional change that occurs in her life, but it is not simply ageing that brings maturity and beauty to someone's character.

"While avidly stealing glances at that person, I was also looking at myself. Lured and led on by that person, I was suddenly ready to grow up" (Kawabata, 1993).

Her readiness to grow up still remains at a mirror level where she looks at the other in comparison to judge her own existence. Instead of a reflection, what is really required is self- realisation that functions independently of the existence of the other, a Master Signifier that determines our true being. The inner experience of the feeling of enlightenment or the realisation about universal good has yet to be experienced by her. Her only obstacle to reach that higher level of existence is obsessive self-love.

"My painful, despairing wish to become beautiful was also because of that person" (Kawabata, 1993).

Miyako-san metamorphosed into a beautiful woman through the mirrored 'otherness'. Her entire life is, more or less, structured by Miss Kikui’s presence.

"I divided my days into the days when I was able to meet that person, and the days when I was not able to meet that person" (Kawabata, 1993).

Even after the most precious self- realisation and becoming mature, when Miyako heard that her teacher is going to leave the school, she still could not make her mind up to see her. Yet, if she missed this opportunity, she would never probably be able to see her true teacher again. She is determined to go to the station to see her leave in the early morning train. "My wish was to prostrate myself before that person, as if just by the sight of her I would somehow be reborn" (Kawabata, 1993). Miss Kikui leaves Miyako's hometown and her school giving her a true new being, another birth, another life, a resurrection. She will remain in Miyako's life forever; a kind of spiritual immortality that mysteriously guides her being for the rest of her life, and even afterwards for many generations to come.

\section{Immortality}

Immortality is part of the anonymity discussed here, which means the teacher remains forever in the students' mind even after s/he has physically left. The values that the teacher inculcated in the subject will function as a guide despite his or her absence. Heroes are immortal and hence remembered simply because of the fact that they perform their duty overcoming their immediate selfinterest. Universal values are immortal and are not time bound and once such a value is once implanted strongly in an individual, it may remain until his or her death. Man's commitment to the highest good would sublimate him to a level of divine existence of immorality. Miss Kikui comes into this small town, stays there for some time doing her duty to the 'other'. Even after Miss Kikui is gone from Miyako's life as a teacher, she remains forever in Miyakosan's life as a person who enlightened her during her younger, immature days. Though she physically left the city as well as Miyako's life, the self-realisation that she imprinted in her is going to last forever in Miyako's mind as a symbolic value system.

“As, trailed by the cries of students, that person's figure in the window grew farther and farther away, by a blessing of heaven, I was standing where the train window was visible into the farthest distance. I was the only one who could see off that person until the very last moment" (Kawabata, 1993).

Obviously, Miyako is the only one who could 'see' the significance of her existence because she was the only one who badly needed such self-reflection to grow into adulthood. On the other hand, Miss Kikui also looks straight at her for the first time, because she knew that Miyako was the most benefitted from her in constructing her identity as a grown-up. They will never meet again. With her "water blue one-piece suit", Miss Kikui disappears back into the clouds like an angel who performed her heavenly spiritual duty to the world, amply receiving the appreciation and honor that Kawabata ascribes to her through the metaphorical language of the organic Japanese tradition.

"Waving her hand, that person disappeared. In the beauty of the movements in her hands, I remembered the dance she taught us in third year. At the edge of the mountain that hid that person's train from view, morning clouds floated in the sky. It was as if that person were waving her hands to me from among the clouds. It was as if she were looking down at me. There was a slight breeze of early autumn. After that, no matter how many letters I wrote to that person's country address, she never answered. Whether it was my girlish dream has reached high-water mark, and that person has brought my buds to full bloom, 
my memories of her no longer hurt my heart. I am at peace now" (Kawabata, 1993).

\section{CONCLUSION}

Kawabata's short story has very effectively depicted the function of a cultural value system as a Master-Signifier which organises a society. Therefore, it becomes a significant moral example in contrast to the postmodern 'detached' approach in the classroom. The story brings in evidence to consider re-defining the present role of teacher and reinstitute him/her as a life example. It clearly illustrates that teacher as change agent intervenes in students' life inculcating what is good. The legitimacy of such act is justified through Miyako's ultimate enlightenment, maturity and desire to move into future. Hence, this short story displays modern characteristic and adds more factual evidence to the Kantian education approach which advocates future better world for humanity through rational education. It also implies a suggestion to revisit Kantian pedagogical notion that education is capable of articulating emancipatory impulses. There is no reason for true teachers to give up their hope since it is a self-referential entity of 'thing-initself'. It can be concluded by quoting one of the greatest French Marxists Louis Althusser (1918-1990), who praises the work of the teacher (though in a completely different context), who fights under difficult sociopolitical conditions to de-mystify the students from historical ideological traps,

"..those teachers, under dreadful conditions, attempt to turn the few weapons they can find in the history and learning they 'teach' against the ideology, the system and the practices they are trapped, are a kind of hero" (Althusser, 2006).

The teacher, as a 'priori', plays an incomparable role in humanising a pupil, undoing his/her natural animalistic impulses and inculcating altruistic value in him/her. Someone's actions would be worthwhile not because they correspond to one's own inclinations but since it reflects duty towards others. Though it may not bring personal profit, pleasure is derived from our interest in what is best for the world, which is the sole source of warmth for our souls. In this demoniac era where all the animalistic desires are promoted and unconsciously exploited to maximise profit, a neo-humanistic project is badly needed to sail upstream. In such virtuous endeavor, the teacher comes to the spotlight more than ever.

"It may be that education will be constantly improved, and that each succeeding generation will advance one step towards the perfecting of mankind, for with education is involved the great secret of the perfection of human nature" (Kant, 1900).

\section{END NOTES}

1. The use of the term 'organic' in the context of this paper derives from its Marxian origin of the phrase 'organic reality'. According to Gramsci (18911937), the distinction between subject and object is minimised when there is a continuous, reciprocal and practical (Praxis) dialogue between the two. Therefore, education takes place when there is an ongoing interaction with the reality, which, in turn, reduces (or eliminates) the ideological distances that individuals create and maintain between self (egoistic knowledge) and external reality. Hence, a teacher should always be in a revolutionary process of practical dialogue with his/her students, changing realities, fellow teacher, administrators etc. for a better understanding of the reality and of the means to change it. For further theoretical insights read Gramsci's Marixism: reclaiming a philosophy of history and politics by Nigel M. Greaves (2009: 216-218) and Gramsci and Marxist theory edited by Chantal Mouffe (1979:51).

2. The reference 'soft skills' or sometimes used as 'corporate skills' is a fairly new term in Sri Lankan higher education. This was mainly introduced to the system by the World Bank funded project called Higher Education for the Twenty First Century (HETC) which came to practice in the first decade in the millennium to introduce radical changes to tertiary education. The incident of training the academics that I refer in the same paragraph was also organised by the said project where the project had hired a trainer from the corporate sector who confidently claimed that 'even Adolf Hitler's public addressing skills can be taken as an example in a classroom in relation to enhancing students' speaking abilities'. In the context of a teacher, what is problematic here is the impossibility of the ethical justifiability of the imaginary boundary that the teacher has to draw between Führer's oratory skill and his political project (sublimated by his speeches) which justified the brutal massacre of millions of Jews. However, one of the key changes that is often highlighted by the said project is Student Centered Learning or, in other words, Outcome Based Education (OBE) where there is a great emphasis on minimising the teacher's role in the classroom. Hence, teacher as a role model or as a moral guide is given little significance in relation to moulding students' moral universe. The future 
dangers that could result from such promotions can surely be immeasurable and its ultimate product would be a generation without a moral compass to distinguish the right from wrong.

3. For further information, read the complete article by Slavoj Zizek in the online edition of the guardian. See the Zizek archive in www.guardian.co.uk.

\section{REFERENCES}

Althusser, L. (2006) Lenin and philosophy and other essays, New Delhi: Aakar Books.

Arendt, H. (1978) Martin Heidegger at eighty, in M. Murray ed. Heidegger and Modern Philosophy: Critical Essays, New Haven: Yale University Press, pp: 293-303.

Badley, G. (2006) The teacher as change agent, British Journal of In-Service Education, 12(03), Taylor and Francis, pp: 150- 158. DOI: http://dx.doi.org/10.1080/0305763860120305

Barth, R. (2001) Learning by heart, San Francisco: Jossey-Bass.

Bauman, Z. (2012) On education: conversations with Riccardo Mazzeo, Cambridge: Polity.

Chen, C. (2005) Teachers as change agents: a study of in-service teachers' practical knowledge, Action in Teacher Education, H.W. Wilson Company, 26(04) pp: 10-19.

Entwistle, H. (1979) Conservative schooling for radical politics, London: Routledge.

Greaves, N. M. (2009) Gramsci's Marixism: reclaiming a philosophy of history and politics, Leicester: Matador Publishing Ltd.

Hanz, H. (1993) Immanuel Kant, UNESCO: Paris: International Bureau of Education.

Hardt, M. \& Negri, A. (2000) The empire, London: Harvard University Press.

Kant, I. (1900) Kant on education, trans. by Annette Churton, Boston: Health and Co., Publishers.

Kant, I. (1963) Critique of pure reason, London: Penguin.

Kawabata, Y. (1993) The morning clouds, trans. by Lane Dunlop, Prairie Schooner, 67. 1. Lincoln: University of Nebraska Press, pp: 6-21.

Lattimer, H. (2012) Agents of change: teacher leaders strengthen learning for their students, their colleagues, and themselves, Official Journal of the Australian Council for the Educational Leaders, 34(04), pp:15-19.
Levitas, R. (1990) The concept of utopia, New York: Syracuses University Press.

Lyotard, J. F. (1984) The Postmodern condition: a report on knowledge, Manchester: Manchester University Press.

Mandel, E. (1971) The changing role of bourgeois universities, Germany: Spartacus League.

Mouffe, C. (1979) Gramsci and Marxist theory, London: Routledge.

Newman, F. \& Couturier, L. (2004) The future of higher education: rhetoric, reality and the risks of the market, San Francisco: Jossey-Bass.

Oxenham, M. (2013) Higher education in liquid modernity, New York: Routledge.

Sartre, J. P. (1946) Existentialism is a humanism, London: Methuen.

Stavrakakis, Y. (2005) Lacan and the political, New York: Routledge.

UNESCO (1998) World education report: teachers and teaching in a changing world, New York: UNESCO Publishing.

Wallerstein, I. (2004) The world system analysis: and introdction, Durham and London: Duke University Press.

Wood, A. (1999) Kant's ethical thought,

London: Cambridge University Press.

DOI:http://dx.doi.org/10.1017/CBO9781139173254

Wright, P. M., Hughes, T. \& Ainley, P. (2001) The provocation of Levinas: rethinking the other, London: Routledge.

Zizek, S. \& Daly, G. (2008) Conversations with Zizek, London: Polity.

Zizek, S. (2014) Living in the end times, London: Verso

Zizek, S. (2007) The invisible remainder: on Schelling and related matters, London: Verso.

Zizek, S. (2013) For Egypt: This is the miracle of the Tahrir Square[online] Available at http://www.theguardian.com/ global/2011/feb/10/egypt-miracle-tahrir-square [Accessed 01 $1^{\text {st }}$ December 2014].

Zizek, S. (2002) For they know not what they do; enjoyment as a political factor, London: Verso.

Films:

Jaws (1975) Film, directed by Steven Spielberg, USA: Universal Pictures. 